\title{
Peningkatan Stabilitas Fitokonstituen Melalui Pendekatan Mikroenkapsulasi
}

\author{
Rosa Riau Wati*, Sriwidodo, Anis Yohana Chaerunisa \\ Departemen Farmasetika dan Teknologi Farmasi, Fakultas Farmasi, Universitas \\ Padjadjaran. \\ JI. Raya Bandung-Sumedang Km. 21 Jatinangor 45363, Sumedang, Indonesia. \\ *Email: rosa19002@mail.unpad.ac.id \\ (Submit 15/8/2021, Revisi 9/9/2021, Diterima 14/12/2021 , Terbit 12/2/2022)
}

\begin{abstract}
Abstrak
Mikroenkapsulasi adalah teknologi untuk menyalut atau melapisi suatu zat inti dengan suatu lapisan dinding polimer sehingga menjadi partikel-partikel berukuran mikro. Tujuan dari mikroenkapsulasi melindungi zat inti dari pengaruh lingkungan, menutupi rasa dan bau tidak enak, menyatukan zat-zat yang tidak tersatukan baik secara fisika maupun secara kimia, menurunkan sifat iritasi zat inti terhadap saluran cerna, mengatur pelepasan inti dan memperbaiki stabilitas bahan inti. Berdasarkan hasil dari para peneliti melalui pendekatan mikroenkapsulsi ini dapat melindungi fitokonstituen dari berbagai faktor lingkungan seperti oksidasi, degradasi, suhu, kelembaban dan cahaya juga dapat memperpanjang umur simpan produk, menutupi rasa dan bau aromatik. Fitokonstituen adalah senyawa-senyawa yang terkandung dalam tumbuhan tertentu. Pendekatan mikroenkapsulasi dapat meningkatkan stabilitas fitokonstituen yang bersifat volatil dan meningkatkan bioavabilitasnya, sehingga mikroenkapsulasi ini dapat digunakan sebagai pilihan untuk fitokonstituen, karena bahan alam berupa ekstrak yang mengandung fitokonstituen umumnya memiliki stabilitas yang tidak stabil, seperti mudah teroksidasi, degradasi, dan fotolisis, selain itu memiliki kelarutan yang rendah dan bioavaibilitas yang rendah. Metode yang digunakan menggunakan beberapa referensi yang didapatkan dari database dan dengan instrumen pencarian online yang diterbitkan secara internasional. Referensi yang didapatkan berasal dari database elektronik seperti google scholar, sciendirect, NCBI dari tahun 2010-2020.
\end{abstract}

Kata kunci: Fitokonstituen , mikroenkapsulasi, stabilitas

\section{Pendahuluan}

Pada pengembangan sediaan farmasi bahan alam, terdapat beberapa jenis bahan yang banyak digunakan diantaranya ekstrak, fraksi, dan isolat. Di Indonesia banyak tanaman yang memiliki fitokonstituen seperti lidah buaya dengan enzim bradikinase, anggur dan teh hijau dengan kandungan polifenol, tomat dengan likopen, mentimun dengan kandungan asam askorbat dan akar manis dengan asam glisiretinat dan stearyl glisiretinat. Tanaman ini berupa ekstrak telah banyak dikembangkan dalam sistem penghantaran baik dalam bentuk sediaan cair maupun sediaan padat (1). 
Ekstrak merupakan sediaan kental yang diperoleh melalui proses ekstraksi baik dengan metode panas atau dingin yang menghasilkan senyawa aktif dengan memperhatikan pelarut yang digunakan (2). Ekstrak dapat berasal dari simplisia nabati maupun hewani (3).

Sediaan Bahan alam yang berupa ekstrak pada umumnya memiliki stabilitas yang kurang baik yang dipengaruhi oleh: ukuran partikel, jenis pelarut, suhu, waktu, $\mathrm{pH}$, rasio pelarut dengan bahan ekstraksi (4-6). Selain itu ekstrak juga bersifat mudah terdegradasi, oksidasi dan fotolisis (7). Pada beberapa jenis ekstrak, terutama menggunakan pelarut non polar tentu akan sulit untuk diberikan secara oral karena memiliki kelarutan yang rendah dan bioavaibilitas yang rendah (8-10). Salah satu cara untuk mengatasi masalah stabilitas tersebut adalah melalui pendekatan mikroenkapsulasi.

Mikroenkapsulasi adalah teknologi untuk menyalut atau melapisi suatu zat inti dengan suatu lapisan dinding polimer sehingga menjadi partikel- partikel berukuran mikro (11) Bahan inti dapat berupa padatan, cair, dan gas. Mikroenkapsulasi yang terbentuk dapat berupa partikel tunggal ataupun dalam bentuk agregat dan biasanya berukuran mikro (12-14). Rentang ukuran 5-5.000 $\mu \mathrm{m}$. Mikroenkapsulasi terdiri dari bahan inti, polimer, dan pelarut (15). Polimer yang digunakan harus bisa memberikan lapisan tipis yang kohesif dengan bahan inti harus bercampur secara kimia, tetapi tidak boleh bereaksi dengan inti (inert) dan memiliki sifat yang sesuai (16).

Mikroenkapsulasi bertujuan melindungi zat inti dari pengaruh lingkungan (17), menutupi rasa dan bau tidak enak, menyatukan zat-zat yang tidak tersatukan baik secara fisika maupun secara kimia.(18), menurunkan sifat iritasi zat inti terhadap saluran cerna, mengatur pelepasan inti dan memperbaiki stabilitas bahan inti. (19).

Keunggulan melalui pendekatan mikroenkapsulasi ini dapat melindungi senyawa dari berbagai faktor lingkungan seperti oksidasi, degradasi, suhu, kelembaban dan cahaya, karenanya dapat memperpanjang umur simpan produk dan menghindari kerusakan ekstrak (1), meningkatkan stabilitas sehingga melindungi senyawa yang penting pada ekstrak (15). Dapat melindungi bahan aktif dan mencegah penurunan aktivitas sehingga meningkatkan stabilitas (20), dapat menutupi rasa dan bau aromatik (21), dapat meningkatkan stabilitas pada senyawa yang bersifat volatil (22), serta dapat meningkatkan bioavabilitas (23).

Berdasarkan uraian diatas disusunlah review artikel ini. Adapun tujuan dari tinjauan ini adalah mengumpulkan informasi tentang penerapan pendekatan mikroenkapsulasi pada tanaman yang memiliki fitokonstituen karena dari hasil beberapa penelitian menunjukkan bahwa bahan alam yang berasal dari ekstrak dimana mengandung fitokonstituen dapat terlindung, meningkatkan stabilitas, dan mencegah penurunan aktivitas. 


\section{Metode}

Dalam artikel tinjauan yang dibuat ini penulis menggunakan beberapa referensi yang didapatkan dari database dan dengan instrumen pencarian online yang diterbitkan secara internasional. Referensi yang didapatkan berasal dari database elektronik seperti google scholar, sciendirect, NCBI dari tahun 2010-2020 menggunakan kata kunci " mikroenkapsulasi" "ekstrak", "stabilitas", "polimer"

\section{Hasil dan Pembahasan}

\section{Mikroenkapsulasi}

Mikroenkapsulasi adalah teknologi untuk menyalut/ melapisi suatu zat inti dengan suatu lapisan dinding polimer sehingga menjadi partikel- partikel berukuran mikro.Bahan inti dapat berupa padatan, cair, dan gas (24) Mikroenkapsulasi yang terbentuk dapat berupa partikel tunggal/ bentuk agregat dan biasanya berukuran mikro. Rentang ukuran 5-5.000 mikrometer. Mikroenkapsulasi terdiri dari bahan inti, bahan penyalut, dan pelarut (15).

Mikroenkapsulasi adalah teknologi penyalutan secara langsung terhadap bahan aktif dalam bentuk partikel yang halus dari zat padatan, cairan, dan bahan-bahan gas dalam kapsul kecil yang melepaskan zat aktif tersebut secara terkontrol $(16,25)$. Mikrokapsul adalah suatu tabung atau paket kecil berukuran mikroskopis dan mempunyai dinding kaku dan halus yang dihasilkan dari proses mikroenkapsulasi hidrofob (26). Mikrokapsul berukuran 1,0-5000 mikrometer dengan bentuk dapat berupa bola, persegi panjang ataupun tidak beraturan (27).

Metode mikroenkapsulasi merupakan salah satu teknik yang paling banyak digunakan untuk melindungi senyawa bioaktif dari berbagai faktor lingkungan seperti penguapan, oksidasi, degradasi suhu kelembaban, dan cahaya karenanya, dapat memperpanjang umur simpan produk dan menghindari kerusakan. (28) dengan melindungi senyawa penting pada ekstrak kulit buah manggis sehingga dapat bertahan lama dan masih dapat dimanfaatkan oleh tubuh dengan baik.(29).

Mikroenkapsulasi merupakan teknologi alternatif untuk meningkatkan penyimpanan dan stabilitas lingkungan dari bioaktif (30). Bisa digunakan untuk melindungi pada kulit manggis dengan pengeringan semprot bisa digunakan sebagai strategi untuk memperlambat oksidasi (31).

Pada teknik mikroenkapsulasi bahan yang digunakan dalam penyalutan dapat berupa polimer (32). Polimer memiliki sifat fisikokimia tertentu sehingga memiliki struktur dan karakteristik yang berbeda (33). Polimer yang digunakan harus mampu memberikan lapisan tipis yang kohesif dengan bahan inti, harus bercampur secara kimia, tetapi tidak boleh bereaksi dengan inti (inert) (34) dan harus memiliki sifat yang sesuai untuk keperluan penyalutan (35). 


\section{Tujuan Mikroenkapsulasi}

Proses Mikroenkapsulasi bertujuan melindungi zat inti dari pengaruh lingkungan (36) menutupi rasa dan bau tidak enak, menyatukan zat-zat yang tidak tersatukan baik secara fisika maupun secara kimia menurunkan sifat iritasi zat inti terhadap saluran cerna, mengatur pelepasan inti dan memperbaiki stabilitas bahan inti (37).

\section{Kelebihan Mikroenkapsulasi}

Kelebihan dari teknologi mikroenkapsulasi ini yaitu dapat melindungi senyawa dari berbagai faktor lingkungan seperti oksidasi bioaktif sehingga menghindari kerusakan ekstrak (29). Meningkatkan stabilitas sehingga melindungi senyawa yang penting pada ekstrak (15), dapat melindungi bahan aktif dan mencegah penurunan aktivitas sehingga meningkatkan stabilitas (20), dapat menutupi rasa dan bau aromatik (21), dapat meningkatkan stabilitas pada senyawa yang bersifat volatil (22), dapat meningkatkan bioavabilitas (38).

\section{Kekurangan dari pendekatan mikroenkapsulasi}

Proses yang cukup rumit dan biaya yang relatif mahal serta penampakan flavor yang sedikit berbeda dari bahan alami (39).

\section{Metode Mikroenkapsulasi}

\section{Penguapan pelarut}

Penguapan pelarut ialah sebagai pelarut untuk menghilangkan dari emulsi yang terdiri dari polimer pelarut organik yang mudah menguap dalam air. Cara terdiri dari empat cara : pelarutan polimer sebagai pelapis dan senyawa aktif dalam pelarut organik untuk membentuk suspensi, emulsi atau larutan, emulsifikasi kation fase organik (fase terdispersi) dalam fase air (fase kontinu) dengan pengadukan, pencampuran statis, ekstrusi atau tetes, penghilangan pelarut dengan penguapan atau ekstraksi cairan, dan pemulihan partikel dengan filtrasi atau sentrifugasi dan pengeringan mikrosfer $(15,40,41)$

\section{Aplikasi Ekstrak Melalui pendekatan Mikroenkapsulasi}

Mikroenkapsulasi yang digunakan pada ekstrak dapat melindungi senyawa, memperpanjang umur simpan, mencegah penurunan aktivitas sehingga meningkatkan stabilitas, dapat menutupi rasa dan bau aromatik, dapat meningkatkan stabilitas pada senyawa yang bersifat volatil, dapat meningkatkan kelarutan dan bioavabilitas (42) seperti terlihat pada tabel 1 . 
Tabel 1 Aplikasi ekstrak melalui pendekatan mikroenkapsulasi dan metode pembuatannya

\begin{tabular}{|c|c|c|c|}
\hline POLIMER & ZAT AKTIF & METODE & REFERENSI \\
\hline $\begin{array}{l}\text { Maltodextrin-accasia } \\
\text { gum }\end{array}$ & $\begin{array}{l}\text { Ekstrak } \\
\text { protein nabati }\end{array}$ & $\begin{array}{l}\text { Pengeringan } \\
\text { semprot }\end{array}$ & $(43)$ \\
\hline Maltodekstrin-NPMR & $\begin{array}{l}\text { Ekstrak daun } \\
\text { maca }\end{array}$ & $\begin{array}{l}\text { Pengeringan } \\
\text { semprot }\end{array}$ & (4) \\
\hline Chitosan & $\begin{array}{l}\text { Ekstrak } \\
\text { Temulawak }\end{array}$ & $\begin{array}{l}\text { Pengeringan } \\
\text { semprot }\end{array}$ & $(44)$ \\
\hline $\begin{array}{l}\text { Getah Arab- Xanthan } \\
\text { gum }\end{array}$ & $\begin{array}{l}\text { Ekstrak } \\
\text { Eschweilera } \\
\text { nana miers }\end{array}$ & Penguapan pelarut & $(31)$ \\
\hline $\begin{array}{ll}\text { Gum } & \text { mete- } \\
\text { Maltodekstrin } & \end{array}$ & $\begin{array}{l}\text { Ekstrak Teh } \\
\text { hijau }\end{array}$ & $\begin{array}{l}\text { Pengeringan } \\
\text { semprot }\end{array}$ & $(45)$ \\
\hline $\begin{array}{l}\text { Sodium Caseinate- } \\
\text { Lendir biji Selada }\end{array}$ & $\begin{array}{l}\text { Ekstrak } \\
\text { Curcumin }\end{array}$ & Penguapan pelarut & $(46)$ \\
\hline $\begin{array}{l}\text { Maltodextrin-gum } \\
\text { arab }\end{array}$ & Ekstrak kunyit & Penguapan pelarut & (43) \\
\hline Eudragit & $\begin{array}{l}\text { Ekstrak cacing } \\
\text { tanah } \\
\text { Lumbricus } \\
\text { Rubellus }\end{array}$ & Penguapan pelarut & $(47)$ \\
\hline $\begin{array}{l}\text { Chitosan-eudragit } \mathrm{s} \\
100\end{array}$ & $\begin{array}{l}\text { Ekstrak kulit } \\
\text { manggis }\end{array}$ & Penguapan pelarut & $(47)$ \\
\hline $\begin{array}{ll}\text { Natrium } \\
\text { chitosan }\end{array}$ & $\begin{array}{l}\text { Ekstrak } \\
\text { jabuticaba }\end{array}$ & Penguapan pelarut & (43) \\
\hline $\begin{array}{l}\text { Chitosan-alginat- } \\
\text { glutaraldehida }\end{array}$ & Ekstrak kunyit & Penguapan pelarut & $(21)$ \\
\hline $\begin{array}{l}\text { Chitosan - protein } \\
\text { whey- gelatin }\end{array}$ & $\begin{array}{l}\text { Ekstrak } \\
\text { Martius }\end{array}$ & Galasi ionik & $(48)$ \\
\hline Chitosan & $\begin{array}{l}\text { Ekstrak } \\
\text { paoniaceae }\end{array}$ & $\begin{array}{l}\text { Pengeringan } \\
\text { semprot }\end{array}$ & (49) \\
\hline Siklodeksterin & Minyak atsiri & Penguapan pelarut & (18) \\
\hline $\begin{array}{l}\text { Gelatin-Natrium } \\
\text { Alginat }\end{array}$ & $\begin{array}{l}\text { Minyak atsiri } \\
\text { Citronella }\end{array}$ & Penguapan pelarut & $(50)$ \\
\hline $\begin{array}{l}\text { Getah arab-starch- } \\
\text { Maltodextrin- inulin }\end{array}$ & $\begin{array}{l}\text { Minyak } \\
\text { esensial } \\
\text { Rusimery } \\
\end{array}$ & $\begin{array}{l}\text { Pengeringan } \\
\text { semprot }\end{array}$ & (23) \\
\hline $\begin{array}{l}\text { Gum arab- polifenol- } \\
\text { Natrium Karsienat }\end{array}$ & Minyak ikan & $\begin{array}{l}\text { Pengeringan } \\
\text { semprot }\end{array}$ & $(51)$ \\
\hline
\end{tabular}




\section{Mikroenkapsulasi pada ekstra}

Proses mikroenkapsulasi diawali dengan ekstraksi bahan alam yang digunakan dimana bahan alam tersebut mengandung metabolit sekunder yang memiliki fitur fitokonstituen. Beberapa referensi telah memaparkan sinstesis untuk pembentukan biofilm dimana fitokonstituen yang terkandung adalah flavonoid, senyawa fenolik, pitosterol, dan glikosida. Fitokonstituen yang berbeda dari berbagai kategori kimia dari sekitar 100 tanaman berbeda yang memodulasi jalur metabolisme yang berbeda seperti glikolisis, siklus Krebs, glukoneogenesis , sintesis dan degradasi glikogen, sintesis kolesterol, metabolisme karbohidrat serta aktivasi reseptor teraktivasi proliferator peroksisom, penghambatan dipeptidyl peptidase dan aksi pemulungan radikal bebas $(52,53)$.

Ekstrak protein nabati dibuat dengan mikroenkapsulasi, dengan cara pengeringan semprot menggunakan campuran polimer untuk melapisi bahan intinya, di lihat dari hasil percobaan nya dapat melindungi dari degradasi dan oksidasi, stabilitas nya stabil pada suhu yang tinggi. Ekstrak daun maca yang dibuat melalui mikroenkapsulasi, dibuat melalui pengeringan semprot menggunakan campuran polimer dilihat dari hasil percobaan nya menjadikan zat inti lebih stabil pada suhu tinggi dan pada masa penyimpanan.

Ekstrak Temulawak yang dibuat melalui pendekatan mikroenkapsulasi dengan cara pengeringan semprot menggunakan polimer tunggal, dari hasil percobaannya mikroenkapsulasi ini dapat memperbaiki sifat fisiko kimia meikrokapsul dengan polimer. Ekstrak Eschweilera nana miers menggunakan campuran polimer, dibuat dengan cara penguapan pelarut, dari hasil percobaan melalui pendekatan mikroenkapsulasi dapat melindungi senyawa pada ekstrak, senyawa aktif tidak berubah ditandai dengan profil KLT.

Ekstrak daun teh hijau dibuat dengan mikroenkapsulasi melalui cara pengeringan semprot menggunakan campuran polimer untuk melindungi bahan intinya. Dilihat dari hasil percobaan stabilitas nya tetap terjaga sehingga melindungi senyawa yang penting pada ekstrak, sehingga pada daun teh hijau aktivitas antioksidannya tetap stabil. Ekstrak curcumin dibuat melalui mikroenkapsulasi dengan cara pengeringan semprot. Menggunakan campuran polimer untuk melindungi bahan inti. Hasil dari percobaan ini dapat meningkatkan kelarutan secara terkontrol melalui enkapsulasi sehingga stabilitas nya tetap stabil dan mencegah oksidasi.

Ekstrak kunyit dibuat dengan mikroenkapsulasi melalui cara penguapan pelarut menggunakan campuran polimer untuk melindungi bahan intinya. Dilihat dari hasil percobaan stabilitas nya tetap terjaga, dapat terlindungi dari degradasi dan oksidatif. sehingga melindungi senyawa yang penting pada ekstrak, sehingga pada ekstrak kunyit aktivitas antioksidannya tetap stabil. Ekstrak cacing tanah Lumbricus Rubellus dibuat dengan mikroenkapsulasi dengan cara emulsifikasi ganda penguapan pelarut, menggunakan polimer tunggal, 
dari hasil percobaan dapat diketauhi melalui mikroenkapsulasi ekstrak cacing tanah Lumbricus Rubellus ini dapat menutupi bau khas cacing tanah dibandingkan dengan ekstrak yang tidak di mikroenpasulasi.

Ekstrak kulit manggis, dibuat dengan mikroenkapsulasi dengan cara pengeringan semprot, menggunakan polimer tunggal untuk melindungi bahan inti nya, dapat dilihat dari hasil penelitian ini dapat melindungi senyawa, dari oksidasi, sehingga stabilitas nya tetap terjaga. Ekstrak Jabuticaba bersifat mudah rusak, di buat dengan mikroenkapsulasi menggunakan campuran polimer untuk melindungi bahan inti dengan menggunakan metode penguapan pelarut. Dapat dilihat dari hasil percobaan melalui mikronkapsulasi stabilitas zat aktif tetap terjaga dan aktivitas tetap stabil ditandai dengan aktivitas yang tidak mengalami penurunan pada hasil percobaan.

Ekstrak Martius pada penelitian ini bertujuan untuk meningkatkan stabilitasnya dan melindungi antosianin dari kondisi lingkungan yang mempengaruhi stabilitas dan warna pada senyawa ini. Dibuat dengan melalui pendekatan mikroenkapsulasi dengan cara galasi ionik, menggunakan campuran polimer untuk melindungi bahan inti. Dilihat dari hasil percobaan stabilitas nya tetap terjaga dengan melindungi bahan aktif, dan aktivitas tetap tidak mengalami penurunan.

Ekstrak paoniaceae dibuat melalui pendekatan mikroenkapsulasi dengan cara pengeringan semprot, menggunakan polmer tunggal untuk melapisi bahan intinya. Hasil penelitian nya dapat dengan mikroenkapsulasi kelarutan nya meningkat, stabilitas nya stabil pada periode penyimpanan dibandingkan dengan ekstaj yang tidak dimikroenkapsulasi.

\section{Mikroenkapsulasi dari Bahan Alam Berupa Minyak}

Pengembangan sediaan bahan alam sekarang telah berkembang ke bahan alam berupa minyak melalui pendekatan mikroenkapsulasi, yang bersifat mudah menguap, dan mudah teroksidasi. Minyak pada matriks polimer digunakan untuk melindungi dari rasa yang tidak enak dan bau yang tidak sedap, sehingga stabilitasnya lebih terjaga dari pengaruh oksidasi.

Minyak atsiri yang dibuat dengan mikroenkapsulasi dimana bersifat mudah mengalami oksidasi, sensitif terhadap cahaya, tidak stabil pada suhu tinggi, menggunakan polimer untuk melindungi bahan intinya dilihat dari hasil percobaan dapat meningkatkan stabilitas dan dapat melindungi dari degradasi oksidatif. Minyak atsiri citronela dibuat melalui pendekatan mikroenkapsulasi dibuat dengan cara penguapan pelarut menggunakan polimer untuk melindungi bahan intinya, dilihat dari hasil percobaan dapat melindungi senyawa dan stabilitas nya stabil pada masa penyimpanan.

Minyak esensial rosemary yang bersifat rasa nya pahit dibuat melalui pendekatan mikroenkapsulasi dengan cara pengeringan semprot menggunakan campuran polimer dari hasil percobaan stabilitas nya tetap terjaga dan dapat menutupi rasa yang pahit. 
Minyak ikan bersifat mudah mengalami oksidasi dibuat melalui pendekatan mikroenkapsulasi dengan cara pengeringan semprot, menggunakan campuran polimer untuk melindungi bahan inti. Dilihat dari hasil percobaan stabilitas nya stabil pada periode penyimpanan.

Tabel 2. Karakteristik Polimer Melalui Pendekatan Mikroenkapsulasi

\begin{tabular}{|c|c|c|c|}
\hline POLIMER & SIFAT & Hasil & Ref. \\
\hline Chitosan & $\begin{array}{l}\text { Biokompabilitas, } \\
\text { Biodegradabilitas }\end{array}$ & $\begin{array}{l}\text { Pelepasan terkontrol, } \\
\text { pembentuk film, }\end{array}$ & $(44)$ \\
\hline Gelatin & $\begin{array}{l}\text { Mudah Teurai, Tidak Beracun, } \\
\text { mudah diikat secara silang }\end{array}$ & Mikrosfer & $(50)$ \\
\hline $\begin{array}{l}\text { Chitosan } \\
\text { Natrium } \\
\text { tripolifosfat }\end{array}$ & $\begin{array}{l}\text { Kationik, Non Toksik, } \\
\text { Biokompabilitas, Biodegradble, } \\
\text { Antimikroba }\end{array}$ & $\begin{array}{l}\text { Meningkatkan Stabilitas, } \\
\text { Menutupi Rasa }\end{array}$ & \\
\hline $\begin{array}{l}\text { Gelatin-Natrium } \\
\text { Alginat /Paraffin }\end{array}$ & $\begin{array}{l}\text { Mudah Teurai, Tidak Beracun, } \\
\text { mudah diikat secara silang / } \\
\text { daya ikat lemah, mudah } \\
\text { meembeku }\end{array}$ & $\begin{array}{l}\text { Meningkatkan } \\
\text { Termal }\end{array}$ & $(50)$ \\
\hline Chitosan- Alginat & Non toksik, Bioavabilitas & Mukoadesif & \\
\hline $\begin{array}{l}\text { PLGA ( poly- } \\
\text { Lactic-co- } \\
\text { Glycolye Acid ) }\end{array}$ & Hidrofobob & Penghantaran obat ke Sel & \\
\hline
\end{tabular}

Maltodexrin Kelarutan tinggi dalam air, Meningkatkan stabilitas,
viskositas rendah, kadar gula memperlama umur simpan endah, dan tidak berwarna

\begin{tabular}{llll}
\hline Siklodekstrin & & $\begin{array}{l}\text { Penghantaran } \\
\text { targeted }\end{array}$ & obat \\
\hline Alginat & Hidrofilik & Sistem penghantaran sel \\
\hline $\begin{array}{l}\text { Gum Acasia dan } \\
\text { maltodextrin }\end{array}$ & $\begin{array}{l}\text { Kelarutan tinggi dalam air, } \\
\text { viskositas rendah, kadar gula } \\
\text { endah, dan tidak berwarna }\end{array}$ & $\begin{array}{l}\text { Stabilisasi degradasi secara kimiawi } \\
\text { serta mencegah terjadinya } \\
\text { penguapan }\end{array}$ \\
\hline Etil selulosa & Tidak larut dalam air & $\begin{array}{l}\text { Pelepasan terkontrol dan } \\
\text { mencegah degradasi, } \\
\text { oksidasi, hidrolisis, dan } \\
\text { kimiawi }\end{array}$ \\
\hline $\begin{array}{l}\text { Natrium Alginat } \\
\text { dan chitosan }\end{array}$ & Tidak dapat larut dalam pelarut \\
\hline $\begin{array}{l}\text { Poly ( urea- } \\
\text { formaldehyde })\end{array}$ & Tensile- stregth dan hardness & Sistem Self- healing \\
\hline
\end{tabular}




\section{Kesimpulan}

Mikroenkapsulasi ini dapat digunakan sebagai pilihan untuk sediaan bahan alam utamanya yang memiliki fitokonstituen yakni dapat berupa ekstrak, karena bahan alam berupa ekstrak umumnya memiliki stabilitas yang buruk, seperti mudah teroksidasi, degradasi, dan fotolisis, selain itu memiliki kelarutan yang rendah dan bioavaibilitas yang rendah. Dengan demikian melalui pendekatan mikroenkapsulasi ini dapat meningkatkan stabilitas ekstrak, melindungi senyawa zat aktif, dan mencegah penurunan aktivitas.

\section{Ucapan Terima Kasih}

Terima kasih kepada Dr.apt Sriwidodo, M.Si dan Dr. rer. nat.apt Anis Yohana Chaerunisaa, M.Si. Selaku pembimbing yang telah memberikan komentar dan saran untuk penyusunan naskah ini.

\section{Referensi}

1. Wathoni N, Yuan C, Yi W, Rostinawati T, Bayu R, Pratiwi R, et al. Heliyon Characterization and antioxidant activity of pectin from Indonesian mangosteen ( Garcinia mangostana L .) rind. Heliyon. 2019;5(August):e02299.

2. Chen Y, Mu T. Application of deep eutectic solvents in biomass pretreatment and conversion. Vol. 4, Green Energy and Environment. 2019. p. 95-115.

3. Battacharyya D, Babgohari MZ, Rathor P, Prithiviraj B. Seaweed extracts as biostimulants in horticulture. Vol. 196, Scientia Horticulturae. 2015. p. 39-48.

4. Lee Y, Chang YH. Jo ur I P re of. Int J Biol Macromol. 2020;

5. Zheng J, Lin ZF, Luo YJ. Preparation and characterization of phenolic aerogels from a new kind of reaction system. Cailiao Kexue yu Gongyi/Material Sci Technol. 2011;19(5).

6. Suprapto S. FORMULASI NAPOLION (NANOPARTIKEL LOTION) ANTIINFLAMASI KOMBINASI EKSTRAK DAUN GELENGGANG DAN SIRIH MERAH. J Farm (Journal Pharmacy). 2019;1(1):1-9.

7. Bevilacqua A, Speranza B, Santillo A, Albenzio M, Gallo M, Sinigaglia M, et al. LWT - Food Science and Technology Alginate-microencapsulation of Lactobacillus casei and $\mathrm{Bi}$ fi dobacterium bi fi dum: Performances of encapsulated microorganisms and bead-validation in lamb rennet. LWT - Food Sci Technol. 2019;113(February):108349.

8. Fan N, Ma P, Wang X, Li C, Zhang X, Zhang K, et al. Storage stability and solubilization ability of HPMC in curcumin amorphous solid dispersions formulated by Eudragit E100. Carbohydr Polym. 2018;199(June):492-8.

9. Cunha SC, Fernandes JO. Extraction techniques with deep eutectic solvents. Vol. 105, TrAC - Trends in Analytical Chemistry. 2018. p. 225-39. 
10. Morales-Gonzalez OM, Zhang C, Li S, Hessel V. Solvent impact assessment for the "One-Flow Functional Solvent Factory." Chem Eng Sci X. 2019;3.

11. Akhavan Mahdavi S, Jafari SM, Assadpoor E, Dehnad D. Microencapsulation optimization of natural anthocyanins with maltodextrin, gum Arabic and gelatin. Int J Biol Macromol. 2016;85:379-85.

12. Dubey R, Shami TC, Bhasker Rao KU. Microencapsulation technology and applications. Def Sci J. 2009;59(1):82-95.

13. Tolve R, Cela N, Condelli N, Di Cairano M, Caruso MC, Galgano F. Microencapsulation as a tool for the formulation of functional foods: The phytosterols' case study. Vol. 9, Foods. 2020.

14. Kaushik P, Dowling K, Barrow CJ, Adhikari B. Microencapsulation of omega-3 fatty acids: A review of microencapsulation and characterization methods. Vol. 19, Journal of Functional Foods. 2015. p. 868-81.

15. Ozkan G, Franco P, De Marco I, Xiao J, Capanoglu E. A review of microencapsulation methods for food antioxidants: Principles, advantages, drawbacks and applications. Food Chem. 2019;272(February 2018):494-506.

16. Hidayah N. Perbandingan berbagai teknik mikroenkapsulasi pakan dalam menghasilkan daging sapi sehat. Semin Nas dan Gelar Prod. 2016;(0736):14351.

17. Guo J, Li P, Kong L, Xu B. Microencapsulation of curcumin by spray drying and freeze drying. LWT. 2020;132(July):109892.

18. Yang C, Lee K, Gul K, Sha M, Kim A, Chun J, et al. LWT - Food Science and Technology Phenolics and antioxidant activity of aqueous turmeric extracts as a ff ected by heating temperature and time. 2019;105(August 2018):149-55.

19. Ramirez E, Dias R, Cintra C, Morais D, Palmiro D, Ascheri R, et al. Microencapsulation of jabuticaba extracts ( $M$ yrciaria cauliflora ): Evaluation of their bioactive and thermal properties in cassava starch biscuits. 2020;(August).

20. Karimi N, Ghanbarzadeh B, Hamishehkar H, Mehramuz B. Antioxidant , Antimicrobial and Physicochemical Properties of Turmeric Extract-Loaded Nanostructured Lipid Carrier ( NLC ). 2018;22(November 2017):18-24.

21. Hasyim N, Indayanti N, Hasan N, Pattang $\mathrm{Y}$. Pembuatan dan Evaluasi Mikrokapsul Ekstrak Cacing Tanah Lumbricus rubellus Dengan Metode Emulsifikasi Ganda Penguapan Pelarut Menggunakan Polimer Eudragit ®. 2016;1(2):11-6.

22. Dima $\mathrm{C}, \mathrm{Pa} \mathrm{L}, \mathrm{Cantaragiu} \mathrm{A}$, Alexe $\mathrm{P}$. The kinetics of the swelling process and the release mechanisms of Coriandrum sativum $L$. essential oil from chitosan / alginate / inulin microcapsules. 2015;

23. Duman F, Kaya M. International Journal of Biological Macromolecules Crayfish chitosan for microencapsulation of coriander ( Coriandrum sativum $L$.) essential oil. Int J Biol Macromol. 2016;92:125-33.

24. Karimi N, Ghanbarzadeh B, Hamishehkar H, Mehramuz B, Kafil HS. Antioxidant, Antimicrobial and Physicochemical Properties of Turmeric Extract-Loaded Nanostructured Lipid Carrier (NLC). Colloids Interface Sci Commun. 2018;22:1824. 
25. Wathoni N, Rahayu SA. A survey of consumer expectation in community pharmacies in Bandung, Indonesia. J Appl Pharm Sci. 2014;4(1):84-90.

26. Estevinho BN, Rocha F, Santos L, Alves A. Microencapsulation with chitosan by spray drying for industry applications - A review. Trends Food Sci Technol. 2013;31(2):138-55.

27. Correâ-Filho LC, Lourenço MM, Moldaõ-Martins M, Alves VD. Microencapsulation of $\beta$-Carotene by Spray Drying: Effect of Wall Material Concentration and Drying Inlet Temperature. Int J Food Sci. 2019;2019.

28. Kamil RZ, Yanti R, Murdiati A, Juffrie M, Rahayu ES. Microencapsulation of indigenous probiotic lactobacillus plantarum dad-13 by spray and freeze-drying: Strain-dependent effect and its antibacterial property. Food Res. 2020;4(6):21819.

29. Wathoni N, Yuan Shan C, Yi Shan W, Rostinawati T, Indradi RB, Pratiwi R, et al. Characterization and antioxidant activity of pectin from Indonesian mangosteen (Garcinia mangostana L.) rind. Heliyon [Internet]. 2019;5(8):e02299. Available from: https://doi.org/10.1016/j.heliyon.2019.e02299

30. Mudrić J, Ibrić S, Đuriš J. Microencapsulation methods for plants biologically active compounds: A review. Lek sirovine. 2018;(38):62-7.

31. Outuki PM, de Francisco LMB, Hoscheid J, Bonifácio KL, Barbosa DS, Cardoso MLC. Development of arabic and xanthan gum microparticles loaded with an extract of Eschweilera nana Miers leaves with antioxidant capacity. Colloids Surfaces A Physicochem Eng Asp. 2016;499:103-12.

32. Feldman D. Polymers and polymer nanocomposites for cancer therapy. Vol. 9, Applied Sciences (Switzerland). 2019.

33. Zhou D, Shanmukaraj D, Tkacheva A, Armand M, Wang G. Polymer Electrolytes for Lithium-Based Batteries: Advances and Prospects. Vol. 5, Chem. 2019. p. 2326-52.

34. Mecerreyes D, Porcarelli L, Casado N. Innovative Polymers for Next-Generation Batteries. Vol. 221, Macromolecular Chemistry and Physics. 2020.

35. Baena-Aristizábal $\mathrm{CM}$, Foxwell $\mathrm{M}$, Wright $\mathrm{D}$, Villamizar-Rivero $\mathrm{L}$. Microencapsulation of Rhizobium leguminosarum bv. trifolii with guar gum: Preliminary approach using spray drying. J Biotechnol. 2019;302(February):3241.

36. Guo J, Liu Z, Gou B, Zeng M. Corrigendum to study of wellbore heat transfer considering fluid rheological effects in deep well acidizing, [volume 191, August 2020, 107171] (Journal of Petroleum Science and Engineering (2020) 191, (S0920410520302588), (10.1016/j.petrol.2020.107171)). Vol. 195, Journal of Petroleum Science and Engineering. 2020.

37. Morais DCM, Abreu DJM de, Mendes D de CS, Alencar UR de, Amorim KA, Damiani C. ANÁLISE DE COMPOSTOS FENÓLICOS TOTAIS E ATIVIDADE ANTIOXIDANTE DE CASCA E POLPA DE MAÇÃ E SUAS RESPECTIVAS FARINHAS. DESAFIOS - Rev Interdiscip da Univ Fed do Tocantins. 2019;6(Especial):5-9. 
38. Dima C, Pətraşcu L, Cantaragiu A, Alexe P, Dima Ş. The kinetics of the swelling process and the release mechanisms of Coriandrum sativum $L$. essential oil from chitosan/alginate/inulin microcapsules. Food Chem. 2016;195:39-48.

39. Boyano-Orozco L, Gallardo-Velázquez T, Meza-Márquez OG, Osorio-Revilla G. Microencapsulation of rambutan peel extract by spray drying. Foods. 2020;9(7).

40. Kameyama A, Haruyama A, Abo H, Kojima M, Nakazawa $Y$, Muramatsu T. Influence of solvent evaporation on ultimate tensile strength of contemporary dental adhesives. Appl Adhes Sci. 2019;7(1).

41. Deshmukh R, Wagh $P$, Naik J. Solvent evaporation and spray drying technique for micro- and nanospheres/particles preparation: A review. Vol. 34, Drying Technology. 2016. p. 1758-72.

42. Jyothi NVN, Prasanna PM, Sakarkar SN, Prabha KS, Ramaiah PS, Srawan GY. Microencapsulation techniques, factors influencing encapsulation efficiency. J Microencapsul. 2010;27(3):187-97.

43. Priol L Le, Dagmey A, Morandat S, Saleh K, Kirat K El, Nesterenko A. Food Hydrocolloids Comparative study of plant protein extracts as wall materials for the improvement of the oxidative stability of sun $\mathrm{fl}$ ower oil by microencapsulation. Food Hydrocoll. 2019;95(April):105-15.

44. Toragall V, Jayapala N, Muthukumar SP, Baskaran V. Biodegradable chitosansodium alginate-oleic acid nanocarrier promotes bioavailability and target delivery of lutein in rat model with no toxicity. Food Chem. 2020;127195.

45. Silva F, Torres L, Silva L, Figueiredo R, Araújo T, Duarte A, et al. A ssamica ) extract encapsulation. Food Chem. 2018;

46. Kavousi HR, Fathi M, Goli SAH. SC. Food Bioprod Process. 2018;

47. Yin J, Xiang C, Song X. Nanoencapsulation of psoralidin via chitosan and Eudragit $\mathrm{S} 100$ for enhancement of oral bioavailability. Int $\mathrm{J}$ Pharm. 2016;510(1):203-9.

48. Gabriela A, Teixeira M, Dias H, Queiroz DF, Baú C, Cazarin B, et al. Anthocyanins from jussara ( Euterpe edulis Martius ) extract carried by calcium alginate beads pre-prepared using ionic gelation. 2019;345:283-91.

49. Sansone F, Picerno P, Mencherini T, Porta A, Lauro MR, Russo P, et al. Technological properties and enhancement of antifungal activity of a Paeonia rockii extract encapsulated in a chitosan-based matrix. J Food Eng. 2014;120(1):260-7.

50. Matos EF De, Scopel BS, Dettmer A. SC. Biochem Pharmacol. 2018;

51. Ninan G, Ravishankar CN. Structural and oxidative stabilization of spray dried fish oil microencapsulates with gum arabic and sage polyphenols: characterization and release kinetics. Food Chem. 2016;

52. Sharma JK, Srivastava P, Ameen S, Akhtar MS, Sengupta SK, Singh G. Phytoconstituents assisted green synthesis of cerium oxide nanoparticles for thermal decomposition and dye remediation. Mater Res Bull. 2017;91:98-107. 
53. Bharti SK, Krishnan S, Kumar A, Kumar A. Antidiabetic phytoconstituents and their mode of action on metabolic pathways. Ther Adv Endocrinol Metab. 2018;9(3):81-100. 